\title{
Identification of fish nursery areas in a free tributary of an impoundment region, upper Uruguay River, Brazil
}

\author{
Patrícia Alves da Silva ${ }^{1}$, David Augusto Reynalte-Tataje ${ }^{1}$ and \\ Evoy Zaniboni-Filho ${ }^{1,2}$
}

This study aims to determine the importance of different environments of the Ligeiro River (upper Uruguay River, Brazil) in fish reproduction. For this purpose, three environments (sampling sites) were selected: rapids, a pool, and the mouth of the Ligeiro River. Ichthyoplankton, zooplankton, and benthos were sampled six times per month from September, 2006 to March, 2007. Zooplankton and ichthyoplankton samples were collected early in the evening with plankton nets $(64 \mu \mathrm{m}$ and $500 \mu \mathrm{m}$, respectively). Benthos samples were also collected early in the evening with a Van Veen dredge. Local abiotic variables (temperature, dissolved oxygen, $\mathrm{pH}$, electrical conductivity, water speed, alkalinity, water hardness, and water transparency) were measured simultaneously with the biotic data sampling and were complemented by regional variables (water flow and precipitation). A total of 43,475 eggs and 2,269 larvae were captured. Of these larvae, $80.1 \%$ were in the preflexion and larval yolk stages. Digestive tract content showed that the greatest degree of repletion among the larvae in more advanced phases occurred in the pool environment. Water speed was the main characteristic used to differentiate the river's rapids and mouth from the pool. The abundance of zooplankton and benthos was not related to the distribution of densities among the different components of the ichthyoplankton. A greater abundance of eggs and larvae with yolk was found in the rapids and river mouth. Ordination analyses showed a connection between the advanced stage larvae and the pool environment. In conclusion, the rapids and river mouth of the Ligeiro River's are important locations for fish reproduction, particularly in regard to spawning and drifting of the ichthyoplankton's initial stages, whereas the pool represents a nursery place for larval growth.

O presente estudo visa determinar a importância de diferentes ambientes do rio Ligeiro (alto rio Uruguai/Brasil) na reprodução dos peixes. Para isto foram selecionados três ambientes (locais): uma corredeira, um poço e a foz do rio Ligeiro. As coletas de ictioplâncton, zooplâncton e bentos foram realizadas seis vezes por mês, entre os meses de setembro de 2006 a março de 2007. As amostras de zooplâncton e ictioplâncton foram coletadas no início da noite com redes de plâncton com malha 64 $\mu \mathrm{m}$ e $500 \mu \mathrm{m}$, respectivamente. A coleta de bentos também aconteceu no início da noite e foi realizada com uma draga de Van Veen. Variáveis abióticas locais (temperatura, oxigênio dissolvido, $\mathrm{pH}$, condutividade elétrica, velocidade da água, alcalinidade, dureza e transparência da água) foram mensuradas simultaneamente as coletas dos dados bióticos e complementadas por variáveis regionais (vazão da água e precipitação). Foi capturado um total de 43.475 ovos e 2.269 larvas; destas, $80,1 \%$ se encontravam nos estágios larval vitelino e pré-flexão. O conteúdo do trato digestório das larvas mostrou que o maior grau de repleção das larvas em estágios mais avançados foi encontrado no poço. A velocidade da água foi o principal fator que discriminou a corredeira e foz do poço. A abundância do zooplâncton e dos bentos não tiveram relação com distribuição das densidades dos diferentes componentes do ictioplâncton. Houve diferença na distribuição dos diferentes componentes do ictioplâncton nos ambientes estudados, com maior abundância de ovos e larvas com vitelo na corredeira e na foz do rio. As ordenações mostraram relação das larvas em estágios avançados com o poço. Conclui-se, portanto, que para a reprodução dos peixes, a corredeira e a foz se apresentam como importantes sítios para a desova dos peixes e deriva dos estágios iniciais do ictioplâncton, enquanto que o poço mostrou relevância como sítio de crescimento das larvas de peixes no rio Ligeiro.

Key words: Eggs, Growth sites, Ichthyoplankton, Larvae, Spawning sites.

\footnotetext{
${ }^{1}$ Universidade Federal de Santa Catarina, Centro de Ciências Agrárias, Departamento de Aquicultura, Laboratório de Biologia e Cultivo de Peixes de Água Doce. Rodovia SC-406, 3532, 88066-000 Florianópolis, SC, Brazil. reynalted@hotmail.com

${ }^{2}$ Universidade Federal de Santa Catarina, Centro de Ciências Agrárias, Departamento de Aquicultura, Programa de Pós-Graduação em Aquicultura. Rodovia Ademar Gonzaga, 1346, 88034-001 Florianópolis, SC, Brazil. zaniboni@cca.ufsc.br
} 


\section{Introduction}

Growth during the early life stages often regulates the recruitment of larval fishes to the adult population (Werner \& Gillian, 1984). Survival through ontogeny depends on becoming sufficiently large to consume increasingly larger prey, on avoiding predation, and on surviving other competitive interactions (Werner \& Gillian, 1984). Consequently, food limitation and consumption during the larval stage has been hypothesized to be the primary factor influencing the survival of larval fishes. The critical-period hypothesis suggests that the availability of food to firstfeeding fishes (exogenous feeding) controls year-class strength (Hjort, 1926). Recently, the match-mismatch hypothesis has expanded the critical-period hypothesis to include not only the feeding stage but also the entire larval period (Cushing, 1990). Specifically, the hypothesis states that temporal and spatial overlap between peaks in food resources (zooplankton, benthos) and larval abundance regulates the survival of larval fishes (Chick \& Van Den Avyle, 1999). In this sense, the success of reproduction and subsequent recruitment is related-where the larvae find an environment with food of sufficient quality and quantity and with the appropriate conditions that promote the active capture of food.

Natural nurseries for fish larvae are perennial or intermittent environments that provide favorable conditions for the development of specific species. High availability of food, low water speed, and reduced predation pressure are some of the main characteristics of these areas (ReynalteTataje et al., 2008a). Environments that are most commonly used by freshwater fish larvae as nurseries include bays, channels, marginal lagoons, pools, margins without currents (Scott \& Nielsen, 1989; Agostinho et al., 1993; King, 2004; Reynalte-Tataje et al., 2008a), and floodplains (Daga et al., 2009; Gogola et al., 2010). Floodplain environments are of great importance for the initial stages of Neotropical fish development (Paiva, 1982; Gogola et al., 2010). The knowledge of the correct location of spawning areas and natural nurseries can serve as an important determinant of conservation efforts and of fish stock management and can provide important data for the identification of critical areas for species conservation (Nakatani et al., 2001).

The upper Uruguay River is located in an enclosed valley. In this region, the river consists of a sequence of pools and rapids, narrows, or waterfalls (Zaniboni-Filho \& Schulz, 2003). The tributaries in this region are short and have many waterfalls, which impedes the movement of fish from the main river to the tributaries and vice versa. Simultaneously, the absence of floodplains and marginal lagoons in most of the river basin requires some fish adaptations to accommodate for the growth of their offspring. Although previous studies have confirmed the spawning of different fish species in this region (Reynalte-Tataje et al., 2008b; Hermes-Silva et al., 2009), little is known about larval feeding and natural nurseries in the upper Uruguay River. This is due mainly to the absence of more developed larvae in samples collected from the upper Uruguay River. According to studies conducted in this region, only $5 \%$ of the total ichthyoplankton organisms were larvae. Of these, only a small proportion represents larvae in more advanced developmental stages (Reynalte-Tataje et al., 2008a).

Some hypotheses assert that regions of the upper Uruguay River, such as the mouth of tributaries (Zaniboni-Filho \& Schulz, 2003), backwaters, and pools, are ideal fish growth areas (Reynalte-Tataje et al., 2008a); however, none of these have been confirmed. It has been hypothesized that the growth of the larvae does not occur in the upper Uruguay River, but rather only in the floodplain of the middle Uruguay River (Hahn, 2000).

This study investigates the hypothesis that variation in the abundance of fish in early development stages and their distribution within the different environments of the Ligeiro River (upper Uruguay River) is related to environmental factors. This study proposes the existence of natural nurseries in the lower regions of the upper Uruguay River tributaries, which may be confirmed by the analysis of the abundance of eggs and of the different larval stages, of the diversity of taxa, of food in the individual digestive tracts, and by the further analysis of these factors in relation to different biotic (e.g., zooplankton and benthic communities) and abiotic variables.

The identification of nursery areas in tributary rivers located in regions with many reservoirs in a cascade may be relevant for the management of watersheds. Such information may be useful in the determination of guidelines for the construction of future hydroelectric projects with minimal impact on the fish community to aid in the conservation of the local fish diversity.

\section{Material and Methods}

\section{Study area}

The Ligeiro River is the only tributary of the Uruguay River that flows into a $10 \mathrm{~km}$ lotic area between the Itá reservoir and the Machadinho dam. This tributary is $215 \mathrm{~km}$ long and has a drainage area of $2,775 \mathrm{~km}^{2}$; the average discharge per month is $191 \mathrm{~m}^{3} / \mathrm{s}$ (ANA, Agência Nacional das Águas). The Ligeiro River has rapids and waterfalls that impede the displacement of fish. The last of these obstacles, located approximately $12 \mathrm{~km}$ from the mouth of the river, is a $5 \mathrm{~m}$ waterfall that represents the first barrier to the fish that come from the main river. Samples were taken in three different environments of this river (Fig. 1). (i) Rapids $\left(27^{\circ} 33^{\prime} 44.4^{\prime \prime} \mathrm{S} 51^{\circ} 51^{\prime} 31.0^{\prime} \mathrm{W}\right)$ comprise an environment measuring approximately $300 \mathrm{~m}$, narrow, shallow (2-4 m), and located in the median portion of the river, at approximately $11 \mathrm{~km}$ from the mouth. (ii) The pool $\left(27^{\circ} 32^{\prime} 12.4^{\prime \prime} \mathrm{S}\right.$ $51^{\circ} 51^{\prime} 38.4^{\prime \prime} \mathrm{W}$ ) comprises a wider environment, approximately $1 \mathrm{~km}$ long, $8 \mathrm{~m}$ deep, located at approximately $2.0 \mathrm{~km}$ upstream from the mouth. (iii) The river mouth $\left(27^{\circ} 31^{\prime} 31.6^{\prime \prime} \mathrm{S} 51^{\circ} 49^{\prime} 57.8^{\prime \prime} \mathrm{W}\right)$, shallow (1-3 m), is located at 


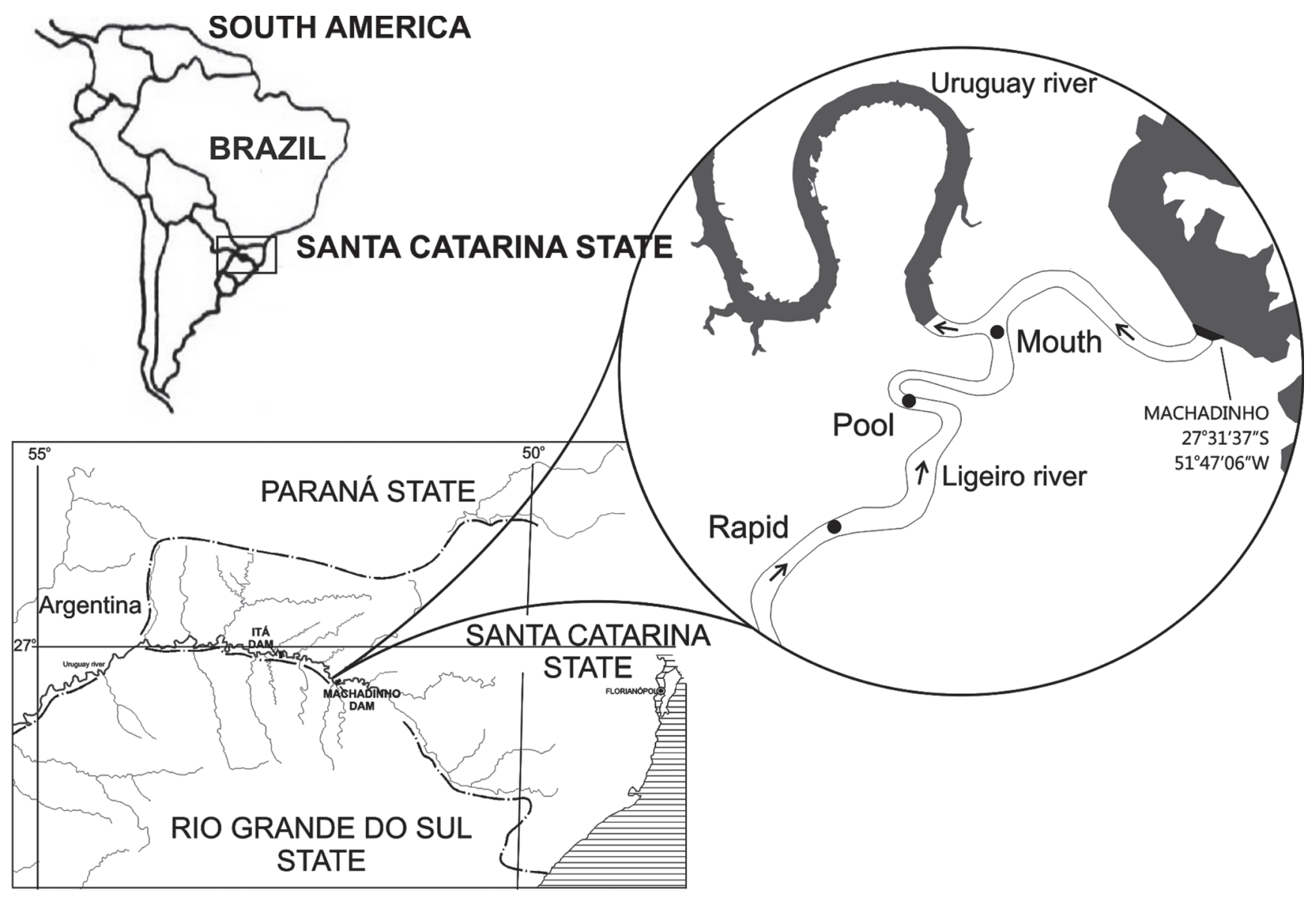

Fig. 1. Sampling sites along the Ligeiro River. $(\rightarrow)$ toward the river; $(\bullet)$ sampling site; river region in gray represents the area of the reservoir.

the opening of the Ligeiro River, approximately $100 \mathrm{~m}$ from its junction with the Uruguay River.

Overall, the three environments are characterized by the presence of basaltic rocks in the bottom and absence of macrophytes. The coastal region flora is composed mainly of grasses and shrubs. This vegetation is submerged only during floods, which were recorded only in the month of September during this study.

\section{Sampling}

Three replicate samples of eggs and larvae per location were collected at five-day intervals between September 2006 and March 2007. Samples were collected at the sub-surface water levels at night $(21: 00 \mathrm{~h})$ with conical-cylindrical plankton nets $\left(500 \mu \mathrm{m}\right.$ mesh) with a mouth area of $0.11 \mathrm{~m}^{2}$. A flowmeter was attached to the mouth of the net to measure the volume of the water filtered. The nets remained in the water for $15 \mathrm{~min}$, connected to the boat by a stretched cable. In the environments where the water speed was less than $0.01 \mathrm{~m} / \mathrm{s}$, the surface trawling was performed with the boat running at low speed. The samples were stored in polyethylene vessels and then labeled and fixed in neutralized $4 \%$ formalin.
The temperature, dissolved oxygen, electrical conductivity, transparency, $\mathrm{pH}$, hardness, and alkalinity were measured. The values of the dissolved oxygen and the water temperature were measured using an YSI-55 oximeter. The values for the $\mathrm{pH}$ and the electrical conductivity were measured using an YSI-63 multi-parameter. A Secchi disk was used to measure the transparency before nightfall. The hardness and alkalinity values were obtained with colorimetric kits (Alfa Tecnoquímica brand). The average water velocity was calculated as previously described by Nakatani et al. (2001). The precipitation and water flow data were provided by ANEEL (Agência Nacional de Energia Elétrica) and by the Consórcio Machadinho.

The zooplankton and benthic organisms were sampled simultaneously in parallel with the sampling of the ichthyoplankton. To sampling zooplankton, three $150 \mathrm{~L}$ samples were collected from the water surface and filtered through a $70 \mu \mathrm{m}$ mesh net. After filtering, the material was concentrated to a volume of $500 \mathrm{~mL}$ and fixed in $4 \%$ formalin. Benthos samples were obtained with a Van Veen dredge $\left(377 \mathrm{~cm}^{2}\right)$. The dredge was thrown three times at each site to sample the benthic community. The material was pre-washed in the field to remove excess sediment by using a $0.5 \mathrm{~mm}$ 
mesh sieve. The material retained by the sieve was stored in containers and preserved in $10 \%$ formalin solution.

\section{Laboratory analysis}

At the laboratory, eggs and larvae were separated from the residual plankton under a stereoscope (10x magnification) by using a Bogorov counting chamber. Egg and larval abundance were standardized to a volume of $10 \mathrm{~m}^{3}$, as previously described by Tanaka (1973).

Larvae were identified to the lowest possible taxonomic level following Nakatani et al. (2001) and Reynalte-Tataje \& Zaniboni-Filho (2008) and were classified in stages according to their degree of development as follows: larval yolk (LY), preflexion (PF), flexion (FL), and postflexion (FP) (Ahlstrom \& Moser, 1976; Nakatani et al., 2001).

Zooplankton samples were concentrated to $50 \mathrm{~mL}$ and were stained for analysis with an alcohol-based Rose-Bengal solution. Sedgewick-Rafter chambers $(2.5 \mathrm{~mL})$ were used to quantitatively analyze the zooplankton with the aid of a microscope (100x magnification). All of the samples were analyzed, and the final density was expressed as individuals $/ \mathrm{m}^{3}$.

Benthos samples were washed under a low pressure water jet in a $0.5 \mathrm{~mm}$ mesh sieve. The material retained by the sieve was stored in $500 \mathrm{~mL}$ vessels and was stained with an alcoholbased Rose-Bengal solution ( $1 \mathrm{~g} / 1,000 \mathrm{~mL})$. Sorting was performed in white PVC trays under a reflected light source. Isolated specimens were preserved in $70 \%$ alcohol.

\section{Digestive tract content analysis}

The digestive tracts from the post-preflexion stage larvae of the ten most frequent species were analyzed for contents. Guts were removed through a longitudinal incision in the abdomen. A degree of repletion was assigned to each digestive tract according to the classification scoring described by Walsh \& Rankine (1979), where $0=$ Empty (absence of food), $1=$ up to $25 \%$ (Partially Empty), $2=26$ to $75 \%$ (Partially Full), and $3=$ over $75 \%$ (Full). Feeding activity in the different environments was analyzed based on the median repletion degree (Gr), according to the equation described by MarçalSimabuku \& Peret (2002): $\mathrm{Gr}=\left(0_{0 \mathrm{n}}+1_{\mathrm{n} 1}+2_{\mathrm{n} 2}+3_{\mathrm{n} 3}\right) /\left(\mathrm{n}_{0}+\mathrm{n}_{1}+\right.$ $\mathrm{n}_{2}+\mathrm{n}_{3}$ ), where, $\mathrm{n} 0 \ldots .3=$ number of samples with repletion degree $0,1,2,3$ e 4 , respectively.

\section{Data analysis}

Space-time variation (sampling sites and months) was evaluated using a two-way ANOVA for log-transformed $\left(\log _{10} \mathrm{x}+1\right)$ densities of the different ichthyoplanktonic, benthic, and zooplanktonic organisms (dependent variables). When results were statistically significant, Tukey's test was applied to detect the differences. A significance level of $\alpha=0.05$ was used for all statistical analysis. The most important species were detected by their average densities during the entire study period and by the frequency of occurrence of each taxa in the samples. The frequency of occurrence was calculated only for fish that were identified up to the genus and species.
To summarize the composition of ichthyoplanktonic organisms in the different sites and months, the density data were ordered using Non-metric Multidimensional Scaling (NMDS). To minimize the effect of rare species on density data, only those with more than $5 \%$ of frequency of occurrence during the study period were selected. To evaluate significant differences of the groups observed on the NMDS, the same data set used for ANOVA was subject to analysis by the Multiple Response Permutation Procedure (MRPP; PCord 5.0 software). To determine the consistency of the groupings in this test, the T-value was used to evaluate their statistical significance, whereas the A-value was used to verify homogeneity among the groups (McCune \& Mefford, 1999).

Canonical Correspondence Analysis (CCA) was used to evaluate the connection between the developmental phases of the ichthyoplanktonic organisms and the set of the environmental variables (ter Braak, 1995). The abiotic data were previously log-transformed $\left(\log _{10} x+1\right)$, with the exception of the $\mathrm{pH}$. The inclusion of the environmental variables in the CCA was based on a forward selection procedure. The statistical significance of the phase-development relationship was tested using the Monte Carlo method (999 randomizations). The fraction of variation of the ichthyoplanktonic organisms was determined using the inertia partitioning method described by Borcard et al. (1992). All ordinations were performed using PCord 5.0 software with a 0.05 significance threshold. Lastly, using the Spearman's rank correlation, the log-transformed densities $\left(\log _{10} x+1\right)$ of the larvae from the most abundant species were correlated with the environmental variables selected by the CCA.

\section{Results}

\section{Taxonomic composition}

A total of 2,269 larvae were captured, representing 4 orders, 16 families, and 29 species. Larvae belonging to Characiformes were the most abundant ( $66.4 \%$ of the total larvae captured), followed by Siluriformes (31.0\%) and Gymnotiformes (1.8\%). The most represented taxa in our samples were from the Characidae (9) and Pimelodidae (6). The remaining families were represented by only one or two taxa (Table 1).

Of the 36 taxa identified, 20 were present at all of the sampling sites. Schizodon nasutus was considered the most important species, as indicated by its frequency of occurrence (15.34\%). It also exhibited the second greatest density during the study period $\left(0.23\right.$ larvae $\left./ 10 \mathrm{~m}^{3}\right)$. Pimelodus maculatus exhibited the highest average density of all of the taxa identified in this study $\left(0.36\right.$ larvae $\left./ 10 \mathrm{~m}^{3}\right)$ and was the second most frequently occurring species (11.36\%). Although it was present in all of the environments, this species was more abundant at the mouth of the tributary (Table 1).

\section{Analysis of digestive tract contents}

A total of 202 digestive tracts of the ten most frequently observed species were analyzed and among these, 145 were empty. Samples from pool exhibited the greatest digestive 
Table 1. Composition, frequency of occurrence ( $\mathrm{FO} \%$ ) and average density (0) (individuals $/ 10 \mathrm{~m}^{3}$ ) of fish larvae during the different months and sampling sites at the Ligeiro River between September 2006 and March 2007. 1- Type of environment; R - rapids; P - pool; M - river mouth; 2 - X- indicates that the species was captured during the marked months; *Less than 0.01 individuals $/ 10 \mathrm{~m}^{3}$.

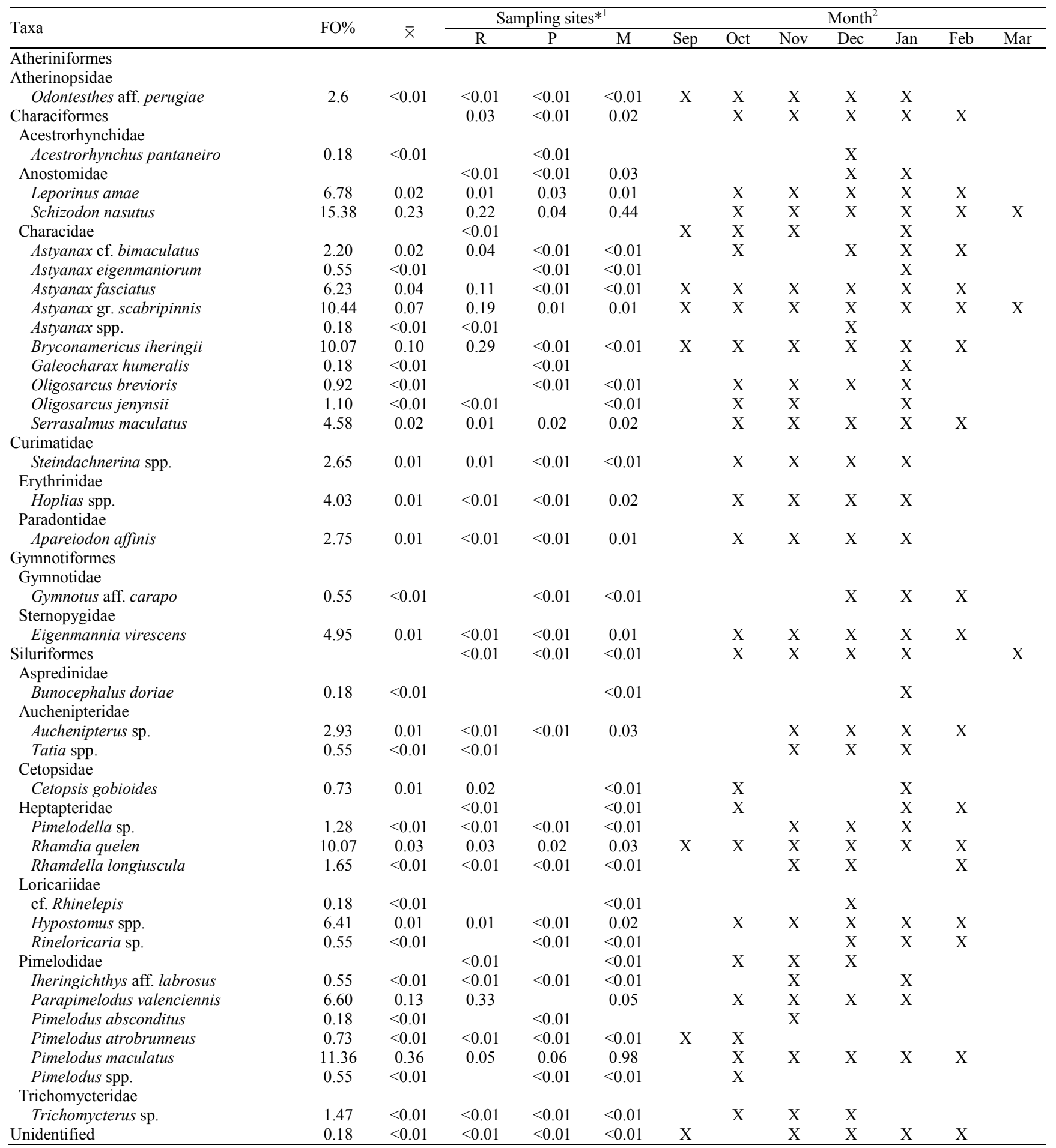


tract repletion degree $(0.70)$ when compared to those from the rapids (0.29) and river mouth (0.54) (Fig. 2).

\section{Spatial-temporal variation of environmental variables and organisms}

Local environmental variables were similar between the studied environments, except for water speed (Table 2). Nevertheless, regional variables differed pronouncedly over time. The average water flow was higher in September (310

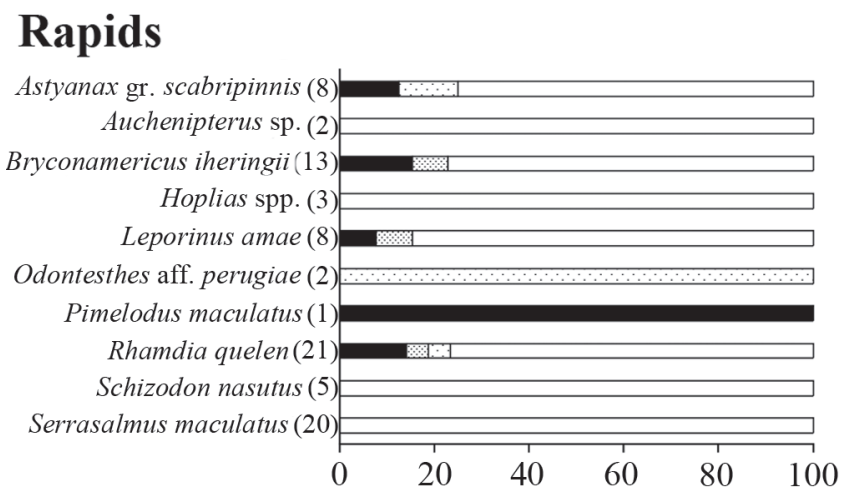

\section{Pool}

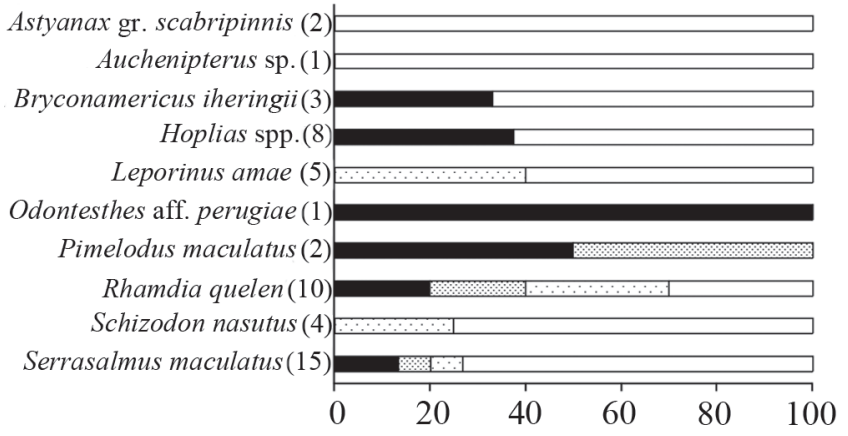

Mouth

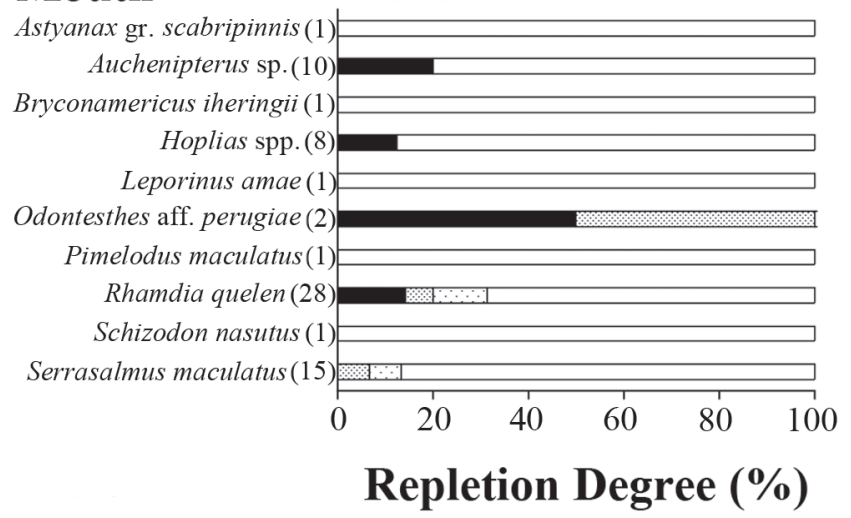

$\square \mathrm{F} \square \mathrm{PF} \square \mathrm{PE} \square \mathrm{E}$

Fig. 2. Degree of fullness of the larval digestive tract in the samples obtained from three locations of the Ligeiro River, during the months of September 2006 through March 2007 (the number of larvae analyzed is shown in parenthesis). $\mathrm{F}=$ Full, $\mathrm{PF}=$ Partially Full; $\mathrm{PE}=$ Partially Empty, E = Empty. $\mathrm{m}^{3} / \mathrm{s}$ ) and decreased gradually during the study period until it reached its lowest value in March $\left(190 \mathrm{~m}^{3} / \mathrm{s}\right)$. The average daily precipitation was highest in November $(2.1 \mathrm{~mm})$ and lowest in October $(0.3 \mathrm{~mm})$.

The maximum density of zooplanktonic organisms was 24,020 individuals $/ \mathrm{m}^{3}$, whereas the density of benthic organisms was 21,901 individuals $/ \mathrm{m}^{2}$. ANOVA revealed significant differences among the distribution of zooplanktonic organisms over space and time $\left(\mathrm{F}_{(12.42)}=6.1702, \mathrm{p}<0.05\right.$, Fig. 3a); the highest densities were recorded for the rapids during the month of September, whereas the highest values for the pool environment were recorded in September and October (Tukey test, $\mathrm{p}<0.05$ ).

No interactions between these biotic factors were observed to affect the benthic organisms ( $>00.05$ ). However, differences were observed for the distribution of benthic organisms over time $\left(\mathrm{F}_{(6.42)}=3.1605, \mathrm{p}<0.05\right.$, Fig. 3b), with the month of October yielding the highest densities (Tukey test; $\mathrm{p}<0.05$ ).

During the study period, 43,475 eggs (95.04\% of the total ichthyoplankton) were collected. Additionally, 2,269 larvae were captured, which represent approximately $5 \%$ of the total ichthyoplankton. Most of the larvae captured $(80.1 \%)$ were in the initial stages of development $(38.0 \%$ in the larval yolk and $42.1 \%$ in the preflexion stages). Only $19.9 \%$ of the sampled larvae exhibited more advanced stages of development: flexion $(17.1 \%)$ and postflexion (2.8\%).

The density of eggs exhibited distribution differences in space and time $\left(\mathrm{F}_{(12,525)}=9.6018 ; \mathrm{p}<0.05\right.$, Fig. 4a). The largest egg catches occurred in the rapids (between the months of October and January) and in the river mouth (October, November, December, and February - Tukey test, $p<0.05$ ).

The larval distribution also exhibited significant differences in space and time $\left(\mathrm{F}_{(12,525)}=6.7644, \mathrm{p}<0.05\right.$, Fig. $4 \mathrm{~b})$. Overall, the larvae were present in all of the environments sampled. The greatest larval densities in the rapids occurred in November and January, and the greatest larvae densities in the river mouth occurred in December and February (Tukey test, $p<0.05$ ). The ANOVA results for the eggs and the larvae are presented in Table 3.

The density of larval stages exhibited differences in regard to their space-temporal distribution at larval yolk, preflexion, and flexion stages. Although only the postflexion stage presented no correlation between these two factors, it did exhibit differences in spatial and temporal distribution (Table 3). The larval yolk stage was the most abundantly detected stage in the river mouth environment in December and in February (Tukey test, $p<0.05$, Figs. $5 a$ and $5 b$ ). The preflexion and the flexion larval stages were more abundant in the rapids in November and in January, respectively (Tukey test, $\mathrm{p}<0.05$, Fig. 5c). Larvae undergoing the postflexion stage were more abundant in November and in the river mouth site (Tukey test, p $<0.05$; Fig. 5d).

When data from the different ichthyoplanktonic stages were compared, two groups could be visually distinguished by NMDS (Fig. 6) and were statistically validated by MRPP $(\mathrm{T}=-1.60, \mathrm{~A}=0.06, \mathrm{p}<0.05)$. In regards to the abundance of the different larval stages, the pool environment exhibited 
Table 2. Average values \pm standard error and minimum-maximum values (in parenthesis) of the observed abiotic variables in the different sampling sites during the study period. *Average value observed among the sampling site.

\begin{tabular}{cccc}
\hline Abiotic variables & \multicolumn{3}{c}{ Sampling sites } \\
\cline { 2 - 4 } & Rapids & Pool & River mouth \\
\hline Temperature $\left({ }^{\circ} \mathrm{C}\right)$ & $24.9 \pm 2.7(18.3-29.6)$ & $24.6 \pm 2.7(17.8-29.0)$ & $24.6 \pm 2.8(18.4-28.8)$ \\
Dissolved oxygen $(\mathrm{mg} / \mathrm{L})$ & $7.9 \pm 0.7(6.9-9.3)$ & $8.7 \pm 1.0(6.7-9.6)$ & $8.3 \pm 0.9(6.6-10.8)$ \\
pH & $7.7 \pm 0.5(6.9-8.6)$ & $7.8 \pm 0.4(7.3-8.5)$ & $7.4 \pm 0.6(5.6-8.1)$ \\
Electrical conductivity & $74.8 \pm 5.8(64.5-82.4)$ & $74.7 \pm 6.4(61.8-81.3)$ & $74.6 \pm 9.5(46.8-111.6)$ \\
Alkalinity $\left(\mathrm{mgCaCO}_{3} / \mathrm{L}\right)$ & $24 \pm 5(16-32)$ & $26 \pm 5(20-36)$ & $26 \pm 5(20-32)$ \\
Hardness $\left(\mathrm{mgCaCO}_{3} / \mathrm{L}\right)$ & $34 \pm 5(24-40)$ & $34 \pm 7(24-48)$ & $32 \pm 4(24-36)$ \\
Transparency $(\mathrm{cm})$ & $68 \pm 43(15-148)$ & $74 \pm 29(20-115)$ & $79 \pm 43(5-150)$ \\
Water speed $(\mathrm{m} / \mathrm{s})$ & $0.84 \pm 0.23(1.21-0.61)$ & $<0.01$ & $0.50 \pm 0.31(0.86->0.01)$ \\
Water flow $\left(\mathrm{m}^{3} / \mathrm{s}\right)^{*}$ & $220 \pm 32(190-310)$ & $220 \pm 32(190-310)$ & $220 \pm 32(190-310)$ \\
Precipitation $(\mathrm{mm})^{*}$ & $1.2 \pm 0.7(0.3-2.1)$ & $1.2 \pm 0.7(0.3-2.1)$ & $1.2 \pm 0.7(0.3-2.1)$ \\
\hline
\end{tabular}

significantly different abundances when compared to the rapids $(\mathrm{T}=-1.82, \mathrm{~A}=0.05, \mathrm{p}<0.05)$ and to the river mouth $(\mathrm{T}$ $=-2.52, \mathrm{~A}=0.10, \mathrm{p}<0.05)$. The rapids and the river mouth exhibited similar larval stage distributions $(\mathrm{T}=0.48, \mathrm{~A}=-0.02$, $\mathrm{p}>0.05)$. In general, more eggs $(\mathrm{r}=-0.72, \mathrm{p}<0.05)$ and larvae in the larval yolk stage $(\mathrm{r}=-0.61, \mathrm{p}<0.05)$ were observed in the rapids and in the river mouth.

\section{Relationship between the environmental factors and the ichthyoplanktonic organisms}

Only the first CCA axis demonstrated significance and revealed a spatial gradient and segregation of larval development stages per area (Fig. 7). Water speed $(r=0.69, p$ $<0.05$ ) was identified by the CCA (forward selection) (Table $4)$ as the most correlated factor with axis 1.

Ichthyoplanktonic stages were related to the set of the environmental variables. In general, the association of the different ichthyoplanktonic stages with water speed at the three sampling sites is reflected in the pattern depicted in Fig. 7. A clear relationship can also be noted between the egg $(r=$
$0.63, \mathrm{p}<0.05)$ and the larval yolk stages $(\mathrm{r}=0.55, \mathrm{p}<0.05)$ and the river mouth and the rapids where the water speed is faster. The preflexion, flexion and postflexion stages could not be clearly correlated with axis $1(p>0.05)$, although they appeared to be more abundant in the pool environment.

\section{Discussion}

\section{Taxonomic composition}

The observed ichthyoplankton population was composed mainly of the larvae of small- and medium-sized fish species that are defined by their many opportunistic characteristics. Such fish species exhibit parceled spawning, long reproductive periods, smaller eggs, shorter migratory displacements and lack of parental care. The results obtained indicate that these species, which are the most abundant in the Itá reservoir (Reynalte-Tataje et al., 2008b), are reproducing in this tributary. For these species, the short lotic stretch spanning 4-5 km between the end of this lake and the river mouth of Ligeiro River, appears to be enough to stimulate
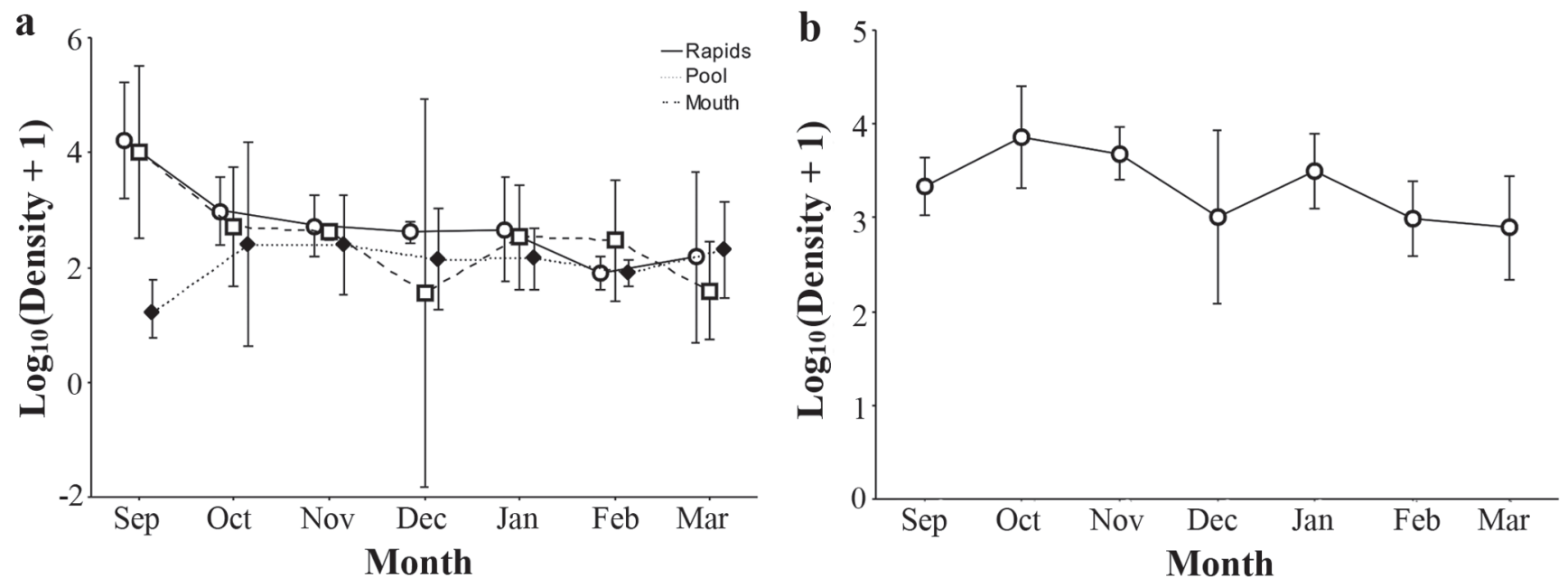

Fig. 3. Average densities ( \pm standard error) of the zooplanktonic organism spatial-temporal distribution (a) and the benthic organism temporal distribution (b) in the sampling sites of Ligeiro River during the months of September through March. 

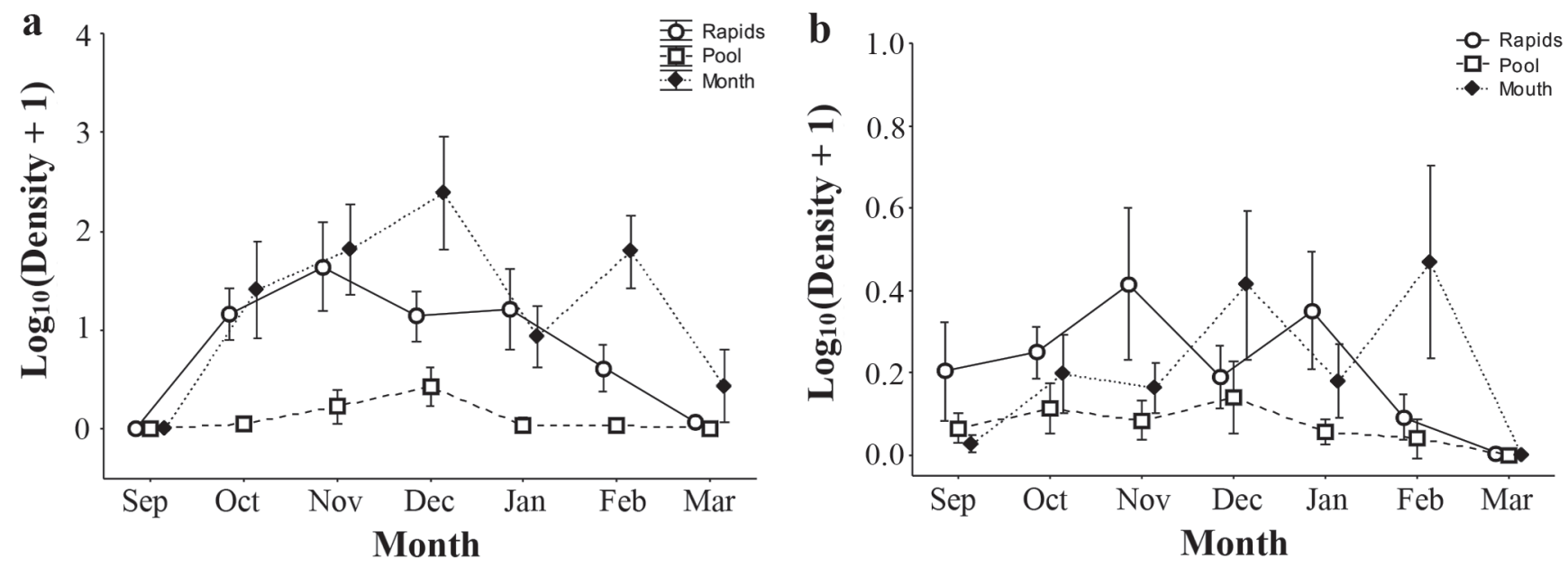

Fig. 4. Average densities ( \pm standard error) of the eggs (a) and the larvae (b) in the sampling sites of Ligeiro River between the months of September 2006 and March 2007.

spawning. In this sense, the reproductive plasticity of these species in Itá reservoir is notable. This plasticity is presented in varying degrees for Schizodon nasutus, Rhamdia quelen and species of the genus Astyanax and Bryconamericus. Species with reduced specific requirements and conditions for habitats, for egg laying, and for the early development of young fish exhibit greater reproductive success in the Ligeiro River and in the other environments in other reservoirs of the upper Uruguay River.

In contrast, the requirement for particular habitats for spawning and early development is characteristic of migratory fish species. Furthermore, the migratory species require "environmental triggers" to spawn, stimuli that are strongly affected by damming. In this sense, the great abundance of larvae of Pimelodus maculatus in the mouth of the tributary needs to be noted. This species, which is highly abundant in the Itá reservoir, but not along the Ligeiro River, appears to be using the lower stretch of this tributary for reproduction. Studies in the lower stretch of this tributary have detected the presence of eggs of this species in the early stages of development (Reynalte-Tataje \& Zaniboni Filho, 2008). Although this species has been considered a migratory species by many authors (Godinho, 1984; Agostinho et al., 2003), the results found in the present study suggest that it may not require long, free migratory stretches for its reproduction.

Of the 98 species recorded in the region of the upper Uruguay River by Zaniboni Filho et al. (2004), 29 use the Ligeiro River as an area for spawning and/or as a nursery. The greatest species diversity was found in the river mouth, which presented 31 of the 36 collected taxa. Despite the variable diversity of the larvae found between the sampling sites, Characiformes and Siluriformes were predominant in all of them, which, according to Lowe-McConnel (1987), is strongly characteristic of Neotropical freshwater environments. In the region of the upper Paraná River, the predominance of these two orders was confirmed by Agostinho et al. (1997), although findings by Baumgartner et al. (2004) suggest that the predominance of a given order in the same region depends on the area and period sampled. The higher abundance of individuals of Characiformes that was detected in this study was also found in the Brazilian Pantanal (Severi, 1997), the upper Paraná River (Baumgartner et al., 1997), and the Amazon Region (AraújoLima \& Oliveira, 1998).

\section{Digestive tract content}

Most Neotropical fish larvae exhibit common characteristics, including reduced size, limited swimming ability, and a rudimentary digestive system. Such characteristics require that larvae find adequate food for their development within the first few days after hatching.

Although the yolk sac is an endogenous source of food that can persist for several days after hatching, some larvae

Table 3. Resuts of the two-way ANOVA applied to the total density of eggs and larvae and to the different larval stages found in three sampling sites of the Ligeiro River (rapids, pool and mouth) from September 2006 through March 2007. $\mathrm{P}$-value $<0.05$ indicates significant statistical difference.

\begin{tabular}{lcccccc}
\hline & \multicolumn{2}{c}{ Eggs } & \multicolumn{2}{c}{ Larvae } & \multicolumn{2}{c}{ Larval yolk } \\
\cline { 2 - 7 } & $\mathrm{F}$ & $\mathrm{P}$ & $\mathrm{F}$ & $\mathrm{P}$ & $\mathrm{F}$ & $\mathrm{P}$ \\
\hline Site & 9.13 & $<0.05$ & 7.24 & $<0.05$ & 18.03 & $<0.05$ \\
Month & 12.83 & $<0.05$ & 9.91 & $<0.05$ & 7.06 & $<0.05$ \\
Site/Month & 7.87 & $<0.05$ & 6.42 & $<0.05$ & 8.02 & $<0.05$ \\
\hline & \multicolumn{2}{c}{ Preflexion } & \multicolumn{2}{c}{ Flexion } & Postflexion \\
\cline { 2 - 7 } & $\mathrm{F}$ & $\mathrm{P}$ & $\mathrm{F}$ & $\mathrm{P}$ & $\mathrm{F}$ & $\mathrm{P}$ \\
\hline Site & 22.91 & $<0.05$ & 1.74 & 0.17 & 3.37 & $<0.05$ \\
Month & 5.05 & $<0.05$ & 6.51 & $<0.05$ & 3.54 & $<0.05$ \\
Site/Month & 2.29 & $<0.05$ & 4.24 & $<0.05$ & 1.24 & 0.25 \\
\hline
\end{tabular}



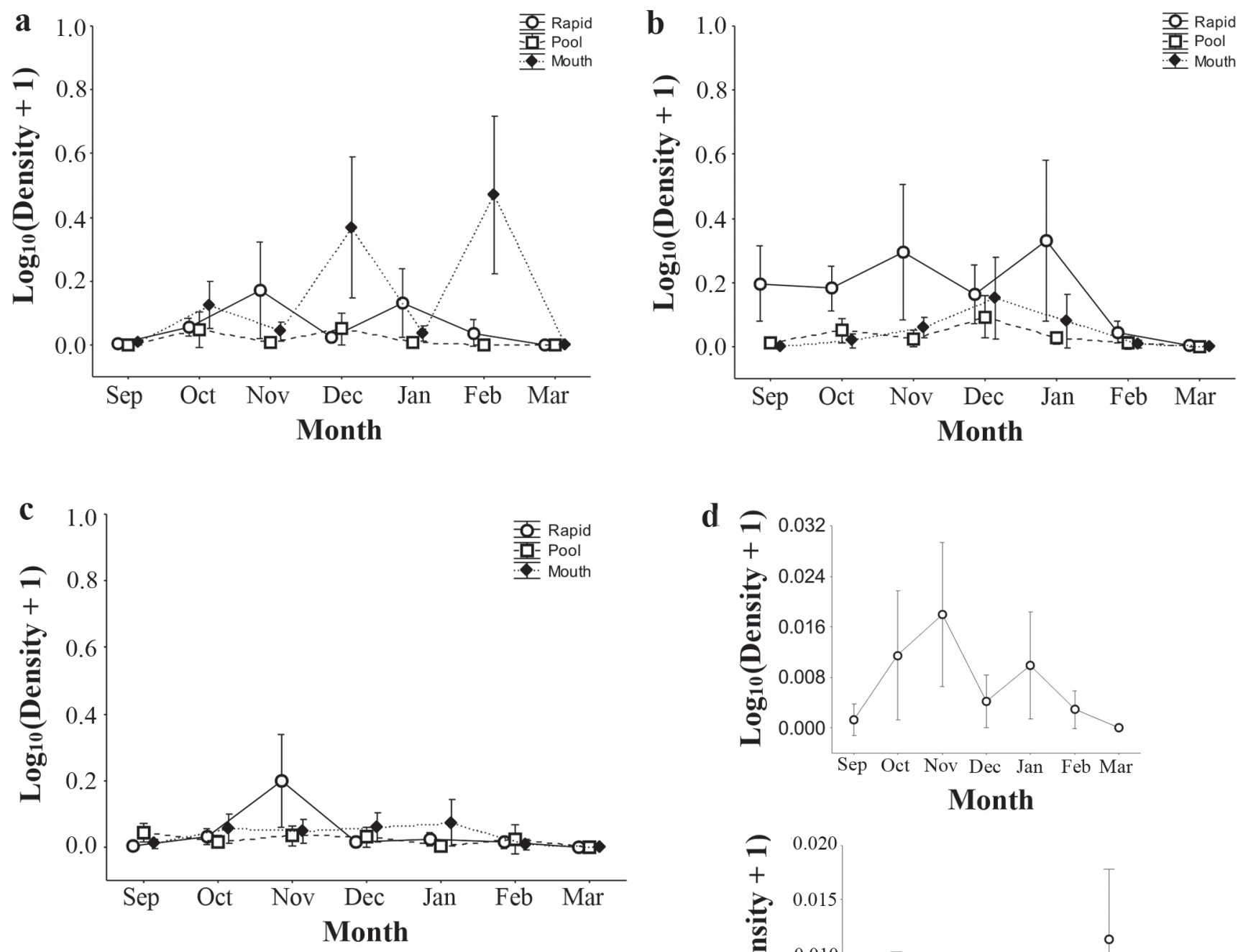

Month

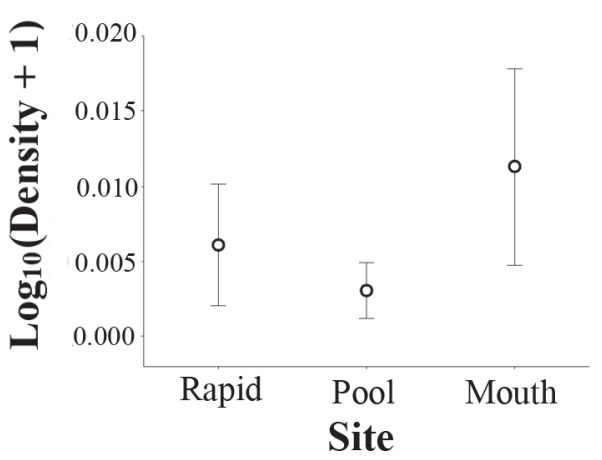

Fig. 5. Average densities ( \pm standard error) of the different larval stages of the samples obtained from three locations of the Ligeiro River, between the months of September 2006 and March 2007: larval yolk (a), preflexion (b), flexion (c), and postflexion (d).

start exogenous feeding before completely absorbing the yolk (Balon, 1986; Kjorvik et al., 1991). Most of the larvae captured during the study period had traces of the yolk sac when the digestive tract was still empty, particularly those undergoing the preflexion stage.

The larvae from the pool area presented the greatest degree of repletion (0.70), which suggests that this environment is associated with the greatest feeding activity among the environments studied. Although the number of the more developed larvae without the presence of yolk was relatively low, the analysis of their stomach content allowed for the verification of the existence of a spatial segregation during the feeding activity. Using Serrasalmus maculatus larvae as an example, all specimens were caught in the rapids and had empty stomachs, indicating that the larvae were just drifting in this environment. The lack of food in the digestive tracts of these larvae can also indicate the absence of adequate food in these environments or the inability of this species to capture food in the environments where water speed is high. Similar hypotheses may be true for Hoplias spp. and Schizodon nasutus larvae considering that they were found feeding in the mouths of the tributary and in the pool. Notably, however, the larvae of some species, such Rhamdia quelen, had digestive contents in all environments. Although the aim of this study was not to determine the food preference of each species - particularly as the number 
of larvae of some species captured that exhibited digestive tract food content was very low -it can be noted that zooplankton and benthos were generally found among the food contents.

\section{Spatial-temporal variation of ichthyoplanktonic abundance}

The Ligeiro River presented a high density of eggs and a low density of larvae. Of the total ichthyoplanktonic organisms captured, $95 \%$ were eggs, and 5\% were larvae. Such a predominance of eggs was also reported in the mouth of three tributaries of the upper Uruguay River and the main river channel (Hermes-Silva et al., 2009; ReynalteTataje et al., 2012) and is considered a pattern for most environments of the upper Uruguay River (Reynalte-Tataje et al., 2008b). The predominance of eggs in the samples in the upper Uruguay River environments may be more evident throughout the La Plata basin (Reynalte-Tataje et al., 2008c).

The largest egg catches occurred between the months of October and February for all of the sampling sites. According to Vazzoler (1996), most of the fish species of the upper Paraná River exhibit their highest reproductive activity between November and January; however, depending on the speciesspecific reproductive strategies, this period may begin as early as September and may persist as late as April. The largest egg captures in the rapids occurred in the months of October and November, while in the mouth of the Ligeiro River it occurred in November, December, and February. This asynchrony suggests that the fish community of the Ligeiro River anticipates spawning when compared to the fish of the Uruguay River, possibly stimulated by the elevated water

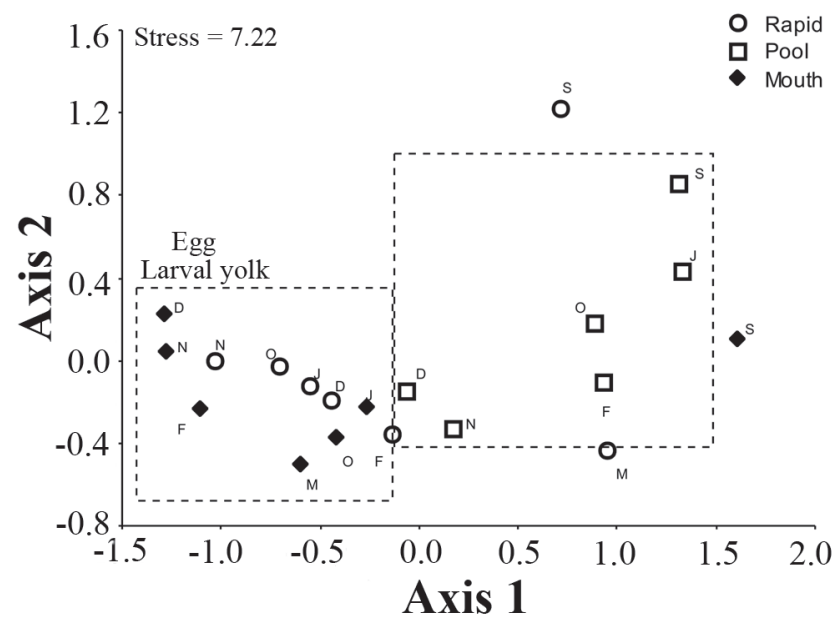

Fig. 6. Biplot of the two first axes resulting from Non Metric Multidimensional Scaling Analysis, showing spatial-temporal segregation of the sampled areas based on the abundance of the different stages of ichthyoplankton found in the Ligeiro River between September 2006 and 2007. S = September; O = October; $\mathrm{N}=$ November; $\mathrm{D}=$ December; $\mathrm{J}=$ January; $\mathrm{F}=$ February; $\mathrm{M}=$ March. temperature observed at this tributary. The temperatures of the Ligeiro River can be approximately 2 to $3^{\circ} \mathrm{C}$ higher than of the main river (Hermes-Silva et al., 2009; Reynalte-Tataje et al., 2012), reaching up to $6^{\circ} \mathrm{C}$ in the early months of the spring season. The anticipation of fish spawning in the tributaries of the upper Uruguay River region was also verified by Reynalte-Tataje et al. (2012).

The fish community of the Uruguay River starts using the mouth region for spawning later, perhaps as a result of the different water temperatures of the two rivers. Several studies emphasize that physical (e.g., water speed, temperature) and chemical differences (e.g., $\mathrm{pH}$, conductivity) at the confluence of two rivers could form a localized physical and/or chemical gradient that might stimulate the fish to spawn a few kilometers upstream from the mouth (Alabaster \& Roberston, 1961; Northcote, 1998; Hohausová et al., 2003). Some cypriniform species are stimulated to spawn by differences in water speed between the main river and the tributary (Northcote, 1998), while the difference in water temperature of the two rivers stimulates ovulation among the perch species, Perca fluviatilis (Berglund, 1978). In the upper Paraná River, the spawning of larger species, such as Salminus brasiliensis, Brycon orbignyanus, and Prochilodus lineatus, was recorded at the confluence area of the rivers and occurs both in the main river and in the tributary (Reynalte-Tataje, 2007). The results found by the studies previously cited may help to understand the greater presence of eggs and larvae in the yolk stage in the mouth of the Ligeiro River.

The same spatial-temporal asynchrony that was found for the eggs was verified for the larvae: in the rapids, the

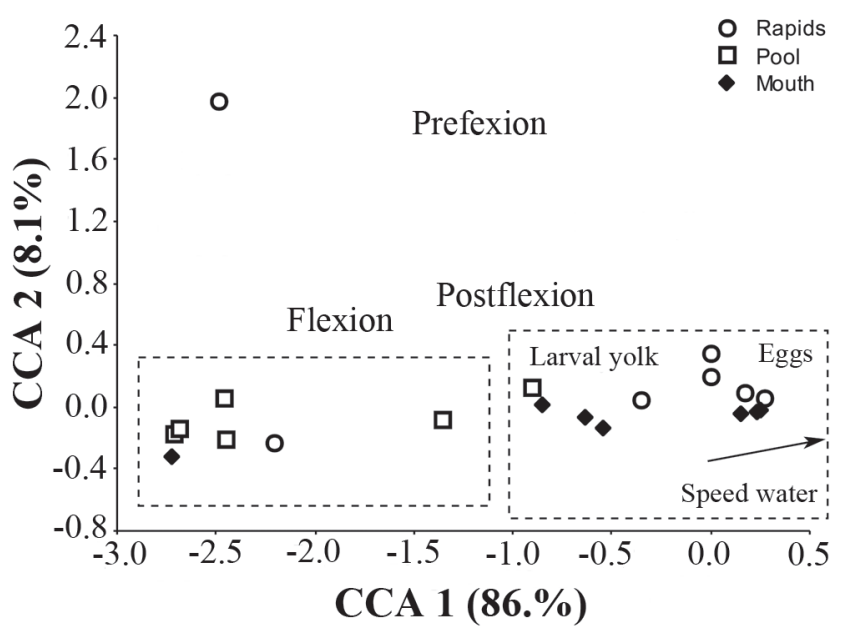

Fig. 7. Biplot resulting from Canonical Correspondence Analysis related to the abundance of the different stages of ichthyoplankton found in three locations of the Ligeiro River (rapids, pool, and mouth) from September 2006 through March 2007. 
Table 4. Results of the Canonical Correspondence Analysis linking the abundance of the different ichthyoplanktonic stages in the sampling sites of the Ligeiro River (upper Uruguay River, Brazil) between September 2006 and March 2007; the Monte Carlo test was used for the significance of the first ordination axis $(\mathrm{P}<0.05 ; \mathrm{n}=999$ permutations $)$. Bold values were statistically significant. Note: Total inertia $=0.411$

\begin{tabular}{lccc}
\hline & Axis 1 & Axis 2 & Axis 3 \\
\hline $\begin{array}{l}\text { Eigenvalues } \\
\text { \% cumulative variance explained by the }\end{array}$ & 0.356 & 0.009 & 0.002 \\
$\begin{array}{l}\text { species-environment relationship } \\
\begin{array}{l}\text { Correlation between ichthyoplanktonic stage } \\
\text { and sites (r) }\end{array}\end{array}$ & 06.6 & 2.2 & 0.6 \\
\hline
\end{tabular}

\begin{tabular}{lc}
\hline Correlation between the environmental variables and the ordination axes \\
Water speed & $\mathbf{0 . 6 9 3}$ \\
Temperature & -0.234 \\
pH & 0.151 \\
Conductivity & 0.204 \\
Dissolved oxygen & 0.301 \\
Transparency & 0.092 \\
Zooplankton & -0.256 \\
Benthos & -0.219 \\
\hline
\end{tabular}

largest captures of these organisms were recorded in November, whereas in the river mouth, the largest captures occurred in December and in February. Such evidence strengthens the hypothesis that fish reproduction is anticipated in the Ligeiro River and may be stimulated by the higher water temperature observed in this tributary.

Although all of the larval stages were found within the different environments sampled, there were some notable differences detected. The rapids were characterized by more eggs and more larvae in the yolk phase, which indicates that this is an area of intense reproductive activity. This environment, which exhibited the highest average water speed among the studied areas, is not characteristic of an area for the growth and development of young fish forms. Thus, the rapids might represent a drift area for these larvae, which move from the spawning areas to the growth areas. The pool had the lowest densities of eggs and larvae of all stages; however, it was characterized by a greater presence of larvae in the more advanced stages of development. Several studies of the inland water regions have found that the more developed larvae that can already move actively prefer environments with lower water speeds (Scott \& Nielsen, 1989; Reynalte-Tataje et al., 2008a). In regards to the ichthyoplanktonic stages, the river mouth exhibited similar egg and larval composition to that of the rapids, indicating that this environment may be used mainly as a spawning area, potentially for the fish populations from the main river.

\section{The influence of environmental factors on ichthyoplanktonic organisms}

Biotic and abiotic factors influence the distribution and abundance patterns of fish species (Norcross \& Shaw, 1984;
Vazzoler et al., 1997; Reynalte-Tataje et al., 2008a). During this study, most abiotic factors did not differ among the studied environments, likely due to their close proximity. The only factor that differed markedly among the areas was water speed, which, according to Thomaz et al. (1997), is a determining factor in maintaining aquatic communities and is associated with this environment's morphological characteristics. The low water speed causes an increase in the water residence time, allowing suspended material to decant and consequently increasing water transparency. These conditions favor the development of planktonic organisms and promote the development of young fish forms (Zaniboni-Filho \& Schulz, 2003). However, such conditions may also facilitate predation and the sedimentation of newly hatched eggs and larvae. Some species change their habitats according to their developmental stage and gradually start to occupy areas with higher water speed (Schiemer et al., 1991). This pattern of distribution was observed in this study, where eggs and larvae in the yolk stage were found in the river mouth and rapids, whereas more developed larvae were more abundant in the pool environment.

Biotic factors were different in terms of space and time. The greatest abundance of zooplanktonic and zoobenthic organisms occurred in September and October, which may be related to an increase in water temperature at the beginning of spring and the greater water flow and precipitation in that region during the winter months of 2006, similar to that recorded by Reynalte-Tataje et al. (2008a) in another tributary of the region. In the rivers, zooplanktonic density tends to rise shortly after floods, particularly in areas with low flow (Welcomme, 1985; Humphries et al., 1999). This pattern seems to similarly apply to the benthic community. During floods, an increase in water level considerably increases levels of organic matter, which may promote the benthic community's development. Studies conducted in other river basins have recorded expressive increases in the populations of planktonic and benthic organisms in river channels shortly after flood peaks (Humphries et al., 1999). Thus, the pronounced increase in water flow in the months leading up to September, combined with the increase in water temperature, may represent decisive factors for the growth of zooplanktonic and benthic populations. In the following months, both the zooplanktonic and the benthic communities underwent reductions. The same pattern was observed by Reynalte-Tataje et al. (2008a) at the Antas River, another tributary of the upper Uruguay River.

The "match-mismatch" hypothesis proposed by Cushing (1990) suggests that the larval growth and survival is greater when there is a synchrony between the periods when they begin exogenous feeding and when there is a greater availability of food. Thus, matching greater densities of feeding-aged larvae and higher concentrations of foraging organisms may be decisive for the success of future recruitment. In this study, the abundance of zooplanktonic and benthic organisms was not significantly related to the different developmental stages of ichthyoplankton, despite their presence in the larval digestive tracts. 
Although there is a pattern of well-distributed rainfall throughout the year for the upper Uruguay River region, rain has typically been concentrated in early spring, particularly in September and October (Sartori, 2003). Although this work represents findings from only one reproductive period, it was conducted during a typical period of concentrated annual rainfall. Therefore, as the regional peak of zooplankton and benthos occurs at a different time than the peak of larvae (usually November to January) (Reynalte-Tataje et al., 2008c), the lack of "match-mismatch" may account for the low percentage of larvae with food content in their digestive tracts. This may also explain the high larval mortality rate during the transition to exogenous feeding (Reynalte-Tataje et al., 2008a), which may account for the low capture rate of larvae in the region. Contrasting the observations in the upper Uruguay River, the coincidence of the flooding period (with subsequent increase of zooplankton and benthic organisms) with the spawning peak has been recorded in other rivers of the $\mathrm{La}$ Plata basin, such as the upper Paraná River and Paraguay (Fuentes et al., 1998; Baumgartner et al., 2004). This coincidence of factors should favor the larval growth and would help to explain the similar proportions in the density of eggs and larvae.

In the present study, despite the absence of a coincidence between the peak of the larvae and of their food, some larvae with food in their digestive tract were nonetheless found mainly in the pool. This environment, due to its lentic characteristics, should facilitate the movement of larvae to capture their food. Although this environment might be expected to house a higher abundance of zooplankton and benthic organisms due to its reduced water speed, such was not detected during most months of the study. Only during September a higher density of food organisms was registered in the pool, although the larval density during this period was low. Thus, we conclude that the increased amount of food in the stomachs of the larvae of different species is more attributable to their ability to seek food in the pools than to the greater abundance of food organisms in this environment.

The identification of nursery areas in the upper Uruguay River is extremely important because the river in this region comprises a sequence of riffles and pools and lacks any floodplain areas. Although we observed a limited presence of foraging organisms in the pools during the reproductive period, the water hydrodynamics observed in this area may facilitate food capturing.

In this study, the rapids and the river mouth were found to be environments of spawning and drifting of eggs and larvae in early stages. The greater water speed impairs the establishment of favorable conditions for the feeding and the survival of more developed larvae. Despite the lower densities of eggs and early-stage larvae, the pools exhibit qualities characteristic of natural nurseries. Thus, greater proportions of more developmentally advanced larvae exhibiting greater feeding activity were found in this environment. These results confirm the presence of areas conducive for fish larval growth in the upper Uruguay River. These findings are of great importance for the region studied, as they identify areas of fish spawning and nursery areas trapped between two reservoirs. Future studies must be conducted in other environments of the upper Uruguay River to better understand the reproductive model found in this unique region and to identify other areas of fish spawning and development.

\section{Acknowledgements}

The authors would like to thank the colleagues from LAPAD (CCA/UFSC) for their help in field sampling and sample sorting. This work is part of the project "Monitoring and management of the ichthyofauna at Itá hydroelectric power station" (Monitoramento e manejo da Ictiofauna da UHE Itá), supported by TRACTEBEL ENERGIA, CAPES and CNPq.

\section{Literature Cited}

Agostinho, A. A., L. C. Gomes, H. I. Suzuki \& H. F. Junior. 2003. Migratory fishes of the Upper Paraná River Basin, Brazil. Pp.135-168. In: Carolsfeld, J., B. Harvey, A. Baer \& C. Ross (Eds.). Migratory fishes of the South America: biology, social importance and conservation status, Victoria, World Fisheries Trust, 372p.

Agostinho, A. A., H. F. Júlio Jr., L. C. Gomes, L. M. Bini \& C. S. Agostinho. 1997. Composição, abundância e distribuição espaço-temporal da ictiofauna. Pp.179-208. In: Vazzoler, A. E. A. M., A. A. Agostinho \& N. S. Hahn (Eds.). A planície de inundação do alto rio Paraná: aspectos físicos, biológicos e socioeconômicos. Maringá, EDUEM, 460p.

Agostinho, A. A., A. E. A. M. Vazzoler, L. C. Gomes \& E. K. Okada. 1993. Estratificación espacial y comportamiento de Prochilodus scrofa em distintas fases del ciclo de vida, en la planície de inundación del alto rio Paraná y embalse de Itaipu, Paraná, Brasil. Revue D’Hydrobiologie Tropicale, 26: 79-90.

Ahlstrom, E. G. \& H. G. Moser. 1976. Eggs and larvae of fishes and their role systematic investigations and fisheries. Revue des Travaux de L'Institut des Peches Maritimes, 40(3-4): 378-398.

Alabaster, J. S. \& K. G. Robertson. 1961. The effect on diurnal changes in temperature, dissolved oxygen and illumination on the behaviour of roach (Rutilus rutilus (L.)), bream (Abramis brama (L.)) and perch (Perca fluviatilis (L.)). Animal Behaviour, 9: 187-192.

Araujo-Lima, C. A. R. M. \& E. C. Oliveira. 1998. Transport of larval fish in the Amazon. Journal of Fish Biology, 53: 297-306.

Balon, E. K. 1986. Types of feeding in the ontogeny of fishes and life-history model. Enviromental Biology of Fishes, 16: 11-24.

Baumgartner, G., K. Nakatani, M. Cavicchioli \& M. S. T. Baumgartner. 1997. Some aspects of the ecology of fish larvae in the floodplain of high Paraná River, Brazil. Revista Brasileira de Zoologia, 14: 551-563.

Baumgartner, G., K. Nakatani, L. C. Gomes, A. Bialetzki, P. V. Sanches \& M. C. Makrakis. 2004. Identification of spawning and natural nurseries of fishes in the upper Paraná River, Brazil. Environmental Biology of Fishes, 71: 115-125.

Berglund, I. 1978. Spawning migration of the Perch, Perca fluviatilis L., in a subarctic Swedish coastal stream. Aquilo Series Zoologica, 18: 43-48.

Borcard, D., P. Legendre \& P. Drapeau. 1992. Partialling out the spatial component of ecological variation. Ecology, 73: 1045-1055. 
Chick, J. H. \& M. J. Van Den Avyle, 1999. Zooplankton variability and larval striped bass foraging: evaluating potential match/ mismatch regulation. Ecological Applications, 9: 320-334.

Cushing, D. H. 1990. Plankton production and year-class strength in fish populations: an update of the match/mismatch hypothesis. Advanced Marine Biology, 26: 249-293.

Daga, V. S., T. M. Gogola, P. V. Sanches, G. Baumgartner, D. Baumgartner, P. A. Piana, E. A. Gubiani \& R. L. Delariva. 2009. Fish larvae assemblages in two floodplain lakes with different degrees of connection to the Paraná River, Brazil. Neotropical Ichthyology, 7: 429-438.

Fuentes, C. M., L. D. Demonte \& M. F. Espoli. 1998. Temporal variation of main channel ichthyoplankton at the end of middle Paraná river. Revista de Ictiologia, 6: 57-64.

Godinho, H. P. 1984. Reprodução dos peixes da represa de Três Marias. Informativo Agropecuário de Belo Horizonte, 10: 29-34.

Gogola, T. M., V. S. Daga, P. R. L. da Silva, P. V. Sanches, E. A. Gubiani, G. Baumgartner \& R. L. Delariva. 2010. Spatial and temporal distribution patterns of ichthyoplankton in a region affected by water regulation by dams. Neotropical Ichthyology, 7: 429-438.

Hahn, L. 2000. Diversidade, composição da ictiofauna e aspectos da biologia de Salminus maxillosus e Prochilodus lineatus do rio Uruguai superior, entre Mondai e Itapiranga, Santa Catarina, Brasil. Unpublished MSc. Dissertation, Pontifícia Universidade Católica do Rio Grande do Sul, Porto Alegre, 86p.

Hermes-Silva, S., D. A. Reynalte-Tataje \& E. Zaniboni-Filho. 2009. Spatial and temporal distribution of ichthyoplankton in the Upper Uruguay River, Brazil. Brazilian Archives of Biology and Technology, 52: 933-944.

Hjort, J. 1926. Fluctuations in the year classes of important food fishes. Journal du Conseil, Conseil Permanenet International Pour L' Exploration de la Mar, 1: 1-38.

Hohausová, E., G. H. Copp \& P. Jankovský. 2003. Movement of fish between a river and its backwater: diel activity and relation to environmental gradients. Ecology Freshwater Fish, 12: 107-117.

Humphries, P., A. J. King \& J. D. Koehn. 1999. Fish, flow and flood plains: links between freshwater fishes and their environment in the Murray-Darling River system, Australia. Environmental Biology of Fishes, 56: 129-151.

King, A. 2004. Density and distribution of potential prey for larval fish in the main channel of a floodplain river: pelagic versus epibenthic meiofauna. River Research and Aplications, 20: 883-897.

Kjorsvik, E., T. Meeren, H. Kryvi, J. Arnfinnsom \& P. G. Kvenseth. 1991. Early development of the digestive tract of cod larvae, Gadus morhua L., during start-feeding and starvation. Journal of Fish Biology, 38: 1-15.

Lowe-McConnel, R. H. 1987. Ecological studies in tropical fish communities. Cambridge University Press, Cambridge, 387p.

Marçal-Simabuku, M. A. \& A. C. Peret. 2002. Alimentação de peixes (Osteichthyes, Characiformes) em duas lagoas de uma planície de inundação brasileira da bacia do rio Paraná. Interciencia, 27: 299-306.

McCune, B. \& C. Mefford. 1999. PC-ORD. Multivariate analysis of ecological data, version 4.1. Oregon, MJM Software Desing, 126p.

Nakatani, K., A. A. Agostinho, G. Baumgartner, A. Bialetzki, P. V. Sanches, M. C. Makrakis \& C. S. Pavanelli. 2001. Ovos e larvas de peixes de água doce: desenvolvimento e manual de identificação. Maringá, EDUEM, 349p.

Norcross, B. L. \& R. F. Shaw. 1984. Oceanic and estuarine transport of fish eggs and larvae: a review. Transactions of the American Fisheries Society, 113: 153-165.
Northcote, T. G. 1998. Migratory behaviour of fish and its significance to movement through riverine fish passage facilities. Pp. 3-18. In: Jungwirth, M., S. Schmutz \& S. Weiss (Eds.). Fish migration and fish bypasses. Oxford, Editora Blackwell Science, 520p.

Paiva, M. P. 1982. Grandes represas do Brasil. Brasília, Editerra Editorial, 304p.

Reynalte-Tataje, D. A. 2007. Influência inter e intra anual de variáveis ambientais sobre a estrutura da comunidade ictioplanctônica em duas bacias hidrográficas brasileiras. Unpublished Ph. D. Dissertation, Universidade Estadual de Maringá, Maringá, 91p.

Reynalte-Tataje, D. A., A. A. Agostinho, A. Bialetzki, S. HermesSilva, R. Fernandes \& E. Zaniboni-Filho. 2012. Spatial and temporal variation of the ichthyoplankton in a subtropical river in Brazil. Environmental Biology of Fishes, 94: 403-419.

Reynalte-Tataje, D. A., S. Hermes-Silva, M. M. C. Silva, F. M. Abbud, R. N. Correa \& E. Zaniboni-Filho. 2008b. Distribuição de ovos e larvas de peixes na área de influência do reservatório de Itá (Alto rio Uruguai). Pp. 127-158. In: Zaniboni-Filho, E. \& A. P. O. Nuñer, (Eds.). Reservatório de Itá. Estudos ambientais, desenvolvimento de tecnologia e conservação da ictiofauna. Florianópolis, Editora UFSC, 319p.

Reynalte-Tataje, D. A., S. Hermes-Silva, P. A. Silva, A. Bialetzki \& E. Zaniboni-Filho. 2008a. Locais de crescimento de larvas de peixes na região do alto rio Uruguai (Brasil). Pp. 159-193. In: Zaniboni-Filho, E. \& A. P. O. Nuñer (Eds.). Reservatório de Itá. Estudos ambientais, desenvolvimento de tecnologia e conservação da ictiofauna. Florianópolis, Editora UFSC, 319p.

Reynalte-Tataje, D. A., S. Hermes-Silva, L. A. Weiss \& E. ZaniboniFilho. 2008c. Distribuição e abundância temporal do ictioplâncton no Alto rio Uruguai. Pp. 195-228. In: ZaniboniFilho, E. \& A. P. O. Nuñer, (Eds.). Reservatório de Itá. Estudos ambientais, desenvolvimento de tecnologia e conservação da ictiofauna. Florianópolis, Editora UFSC, 319p.

Reynalte-Tataje, D. A. \& E. Zaniboni-Filho. 2008. Biologia e identificação de ovos e larvas de peixes do alto rio Uruguai. Pp. 229-256. In: Zaniboni-Filho, E. \& A. P. O. Nuñer (Eds.). Reservatório de Itá. Estudos ambientais, desenvolvimento de tecnologia e conservação da ictiofauna. Florianópolis, Editora UFSC, 319p.

Sartori, M da B. G. 2003. A dinâmica do clima do Rio Grande do Sul: indução empírica e conhecimento científico. Terra Livre, 20: $27-49$.

Schiemer, F., T. Spindler, H. Wintersberger, A. Schneider \& A. Chovanec. 1991. Fish fry associations: important indicators for the ecological status of large rivers. Verhandlungen des Internationalen Verein Limnologie, 24: 2497-2500.

Scott, M. T. \& L. A. Nielsen. 1989. Young fish distribution in the backwaters and main channel borders of the Kanawha River, West Virginia. Journal of Fish Biology, 35: 21-27.

Severi, W. 1997. Ecologia do ictioplâncton no pantanal de Barão de Melgaço, bacia do rio Cuiabá, Mato Grosso, Brasil. Unpublished Ph.D. Dissertation, Universidade Federal de São Carlos, São Carlos, 264p.

Tanaka, S. 1973. Stock assessment by means of Ichthyoplankton surveys. FAO Fisheries Technical Paper, 122: 33-51.

Ter Braak, C. J. F. 1995. Ordination. Pp. 91-173. In: Jongman, R. H. G., C. J. F. Ter Braak, \& O. F. R. van Tongeren (Eds.). Data analysis in community and landscape ecology. Cambridge, Cambridge University Press, 298p.

Thomaz, S. M., M. C. Roberto \& L. M. Bini. 1997. Caracterização limnológica dos ambientes aquáticos e influência dos níveis 
fluviométricos. Pp. 73-102. In: Vazzoler, A. E. A. M., A. A. Agostinho \& N. S. Hahn (Eds.). A planície de inundação do alto rio Paraná: Aspectos físicos, biológicos e socioeconômicos. Maringá, EDUEM, 460p.

Vazzoler, A. E. A. M. 1996. Biologia da reprodução de peixes teleósteos: teoria e prática. Maringá, EDUEM, 169p.

Vazzoler, A. E. A. M., M. de Los A. P. Lizama, \& P. Inada. 1997. Influências ambientais sobre a sazonalidade reprodutiva. Pp. 267280. In: Vazzoler, A. E. A. M., A. A. Agostinho \& N. S. Hahn (Eds.). A planície de inundação do alto rio Paraná: Aspectos físicos, biológicos e socioeconômicos, Maringá, EDUEM, 460p.

Walsh, M. \& P. Rankine. 1979. Observations on the diet of mackerel in the North Sea and to the west of Britain. International Council for the Exploration of the Sea, 8p.

Welcomme, R. L. 1985. River Fisheries. FAO Fisheries Technical Paper 262. Rome, Food and Agriculture Organization of the United Nations, 240p.

Werner, E. E. \& J. F. Gillian. 1984. The ontogenetic niche and species interactions in size-structured populations. Annual Review of Ecology and Systematics, 15: 393-425.

Zaniboni-Filho, E., S. Meurer, O. A. Shibatta \& A. P. O. Nuñer. 2004. Catálogo ilustrado de peixes do Alto Rio Uruguai. Florianópolis, Editora UFSC/Tractebel Energia, 128p.

Zaniboni-Filho, E. \& U. H. Schulz. 2003. Migratory fishes of the Uruguay River. Pp.135-168. In: Carolsfeld, J., B. Harvey, A. Baer \& C. Ross (Eds.). Migratory fishes of the South America: biology, social importance and conservation status, Victoria, World Fisheries Trust, 372p.

Submitted June 2, 2011

Accepted May 20, 2012

Published June 29, 2012 